\section{JURNAL ABDIMAS

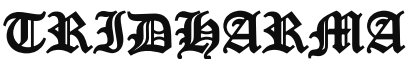

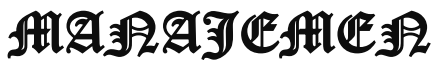

P-ISSN 0000-0000, E-ISSN 0000-0000

Jurnal ABDIMAS Vol.1,No.1,Agustus 2019, Hal (118-126)

@Prodi Manajemen Fakultas Ekonomi Universitas Pamulang

Email: abdimasjurnal.unpam@gmail.com Telp: (021) 741-2566

\title{
PENYULUHAN PEMBINAAN AQIDAH PADA ANAK-ANAK USIA DINI GUNA PENGAMBILAN KEPUTUSAN DALAM ILMU MANJEMEN DI PANTI PENYANTUNAN ANAK -ANAK YATIM PIATU AL MUBAROKAH
}

Eka Rahim,Ermah Ermawati, Ifa Nurmasari,Laura Komala ,Lucia Maduningtias

\author{
Email : ekarahim1409@gmail.com ,dosen01550@unpam.ac.id \\ dosen01013@unpam.ac.id, dosen01783@unpam.ac.id
}

\begin{abstract}
ABSTRAK
Pengabdian ini berjudul Penyuluhan Pembinaan Aqidah Pada Anak -Anak Usia Dini Guna Pengambilan Keputusan Dalam Ilmu Manajemen Di Panti Penyantunan Anak -Anak Yatim Piatu Al Mubarokah
\end{abstract}

Tujuan pengabdian ini adalah dengan pembinaan aqidah dalam pengambilan keputusan dalam ilmu manajemen dalam rangka pencapaian regiulitas dengan resiliensi pada anak usia dini di panti asuhan Almubarokah. Metode pelaksanaan pengabdian ini dilakukan dalam beberapa kegiatan yaitu tahap survei yaitu sosialisasi dilakukan dengan menyusun berbagai hal yang akan disampaikan pada saat kegiatan pengabdian yang akan dilakukan yang meliputi: penyusunan materi yang akan diberikan, penyusunan jadwal pemberian materi, pembagian tugas tim pengabdian dan survei ke lokasi pengabdian. Tahap sosialisasi yaitu sebelum kegiatan pengabdian dilaksanakan terlebih dahulu dilakukan tahap sosialisasi yaitu melakukan silaturahmi dengan ketua yayasan, menyampaikan maksud dan tujuan pengabdian ini. Pada tahap ini juga dilakukan jalinan kerjasama dan menentukan jadwal kegiatan pengabdian. Tim pelaksana kegiatan pengabdian pada masyarakat adalah dosen Fakultas Ekonomi jurusan manajemen sebanyak 11 orang. Tim pengabdian memberikan materi tentang materi terkait dengan pembinaan aqidah dalam pengambilan keputusan dalam ilmu manajemen dalam rangka pencapaian regiulitas dengan resiliensi pada anak usia dini di panti asuhan Almubarokah Cipayung -Ciputat dan bekerjasama dengan Yayasan Panti Asuhan Al Mubarokah .

Kesimpulan dari pengabdian ini adalah materi tersampaikan dengan mudah dimengerti serta dipahami oleh para anak usia dini pada panti asuhan Almubarokah Ciputat Kota Tangerang Selatan Banten.

Kata Kunci : Pembinaan Aqidah, penyuluhan aqidah dan akhlak .

ABSTRACT 


\section{JURNAL ABDIMAS

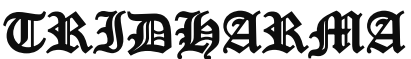

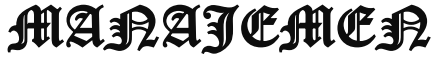

P-ISSN 0000-0000, E-ISSN 0000-0000

Jurnal ABDIMAS Vol.1,No.1,Agustus 2019, Hal (118-126)

@Prodi Manajemen Fakultas Ekonomi Universitas Pamulang

Email: abdimasjurnal.unpam@ gmail.com Telp: (021) 741-2566

This dedication is titled Counseling Aqidah Coaching For Children - Early Childhood For Decision Making In Management Science At Child Care Institution - Orphan Children Al Mubarokah

The purpose of this dedication is by fostering aqeedah in decision making in management science in the context of achieving regiulity with resilience in early childhood in the Almubarokah orphanage. The method of implementing this service is carried out in a number of activities, namely the survey stage, namely the socialization carried out by arranging various things to be delivered at the time of service activities that will be carried out which include: preparation of material to be given, preparation of material delivery schedule, division of tasks of the service team and survey to the location devotion. The socialization phase is before the community service activities are carried out first, the socialization stage is to make a friendship with the chairman of the foundation, conveying the aims and objectives of this service. At this stage also carried out the fabric of cooperation and determine the schedule of service activities. The implementing team of community service activities are 11 lecturers at the Faculty of Economics majoring in management. The dedication team provided material on material related to aqidah guidance in decision making in management science in the context of achieving regiulity with resilience in early childhood at the Cipayung Almubarokah orphanage and Ciputung and collaborating with the Al Mubarokah Orphanage Foundation.

The conclusion of this dedication is that the material is easily understood and understood by young children at the Ciputat Almubarokah orphanage, South Tangerang City, Banten.

\section{Keywords: Aqidah guidance, aqidah counseling and morals.}

\section{PENDAHULUAN}

Panti Asuhan merupakan lembaga yang bergerak di bidang sosial untuk membantu anak-anak yang sudah tidak memiliki orang tua. Di dalam Kamus Besar Bahasa Indonesia (2001), panti asuhan merupakan sebuah tempat untuk yang bergerak di bidang sosial untuk membantu anak-anak yang sudah tidak memiliki orang tua. Di dalam Kamus
Besar Bahasa Indonesia (2001), panti asuhan merupakan sebuah tempat untuk merawat dan memelihara anak-anak yatim atau yatim piatu.

Pengertian yatim adalah tidak memiliki seorang ayah, sedangkan yatim piatu adalah tidak memiliki seorang ayah dan ibu. Namun, tidak hanya untuk anak yatim maupun yatim piatu, panti asuhan 


\section{JURNAL ABDIMAS

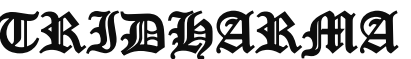

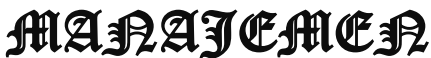

P-ISSN 0000-0000, E-ISSN 0000-0000

Jurnal ABDIMAS Vol.1,No.1,Agustus 2019, Hal (118-126)

@ Prodi Manajemen Fakultas Ekonomi Universitas Pamulang

Email: abdimasjurnal.unpam@gmail.com Telp: (021) 741-2566 juga terbuka untuk anak-anak selain mereka, seperti anak terlantar.

Anak- anak yang kurang beruntung seperti yang dipaparkan di atas juga dapat bertempat tinggal di panti asuhan. Jumlah panti asuhan di seluruh Indonesiadiperkirakan antara 5.000-8.000 yang mengasuh sampai setengah juta anak. Pemerintah Indonesia hanya memiliki dan menyelenggarakan sedikit dari panti asuhan tersebut, lebih dari $99 \%$ panti asuhan diselenggarakan oleh masyarakat, seperti anak yatim, anak piatu, anak yatim piatu, anak terlantar dan anak yang tidak mampu.

Bertempat tinggal dan hidup di panti asuhan bukanlah hal yang mudah bagi anak, khususnya bagi remaja. Karena mereka tidak mendapatkan hangatnya kasih sayang orang tua kandung.

Santi (2011) dalam makalahnya menjelaskan bahwa dalam penelitian yang telah dilakukan oleh lembaga Save The Children, terdapat kasus-kasus eksploitasi terhadap anak di dalam panti asuhan, sehingga fungsi panti asuhan sebagai lembaga asuhan alternatif tidak dapat melindungi anak yang berada di luar asuhan keluarga secara aman.

Sebaliknya anak-anak tumbuh dalam lingkungan yang tidak kondusif, tidak protektif yang akan mengganggu terhadap tumbuh kembang anak. Menurut Monks, dkk (dalam Desmita, 2012) masa remaja dibedakan menjadi

empat bagian, yaitu (1) pra-remaja atau prapubertas (10-12 tahun), (2) remaja awal atau pubertas (12-15 tahun), (3) remaja pertengahan (15-18 tahun) dan (4) remaja akhir (18-21). siliensi remaja panti asuhan dapat dilihat dari beberapa indikator, yaitu memiliki emosi yang stabil, peka terhadap orang lain, percaya diri, bekerja keras, optimis, mengerti kondisi diri sendiri, mampu mengendalikan diri, berani mengambil keputusan serta mempunyai tujuan hidup yang jelas. Hal ini berlawanan dengan indikator individu yang memiliki resiliensi rendah, yakni kurang mampu mengatur emosi sehingga mudah marah, memiliki kepercayaan diri yang rendah, sulit mengambil keputusan, tidak memiliki tujuan hidup dan cenderung memiliki emosi negatif.

Jika remaja panti mempunyai resiliensi yang baik, maka akan mampu mengatasi segala permasalahan yang ada. Resiliensi yang dimiliki remaja dapat menjadi pelindung sehingga tidak memberi dampak yang negatif dalam kehidupan mereka, remaja yang memiliki resiliensi yang tinggi lebih tahan terhadap stress, memiliki strategi yang baik dalam memperbaiki suasana hati yang negatif dan lebih sedikit mengalami gangguan emosi dan perilaku (Hauser, 1999).

Begitu pula dengan remaja di panti asuhan, dalam keadaan yang menekan diharapkan remaja memiliki resiliensi sehingga mampu menghadapi segala macam permasalahan dan mampu bangkit dan tetap produktif. Remaja yang bangkit dari keterpurukanResiliensi memiliki beberapa faktor yang mempengaruhinya, salah satunya adalah religiusitas.

$\begin{array}{ccr}\text { Religiusitas diyakini } & \text { mampu } \\ \text { memberikan } & \text { kontribusi } & \text { dalam }\end{array}$




\section{JURNAL ABDIMAS

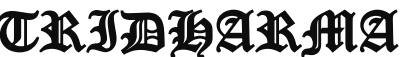 MA:}

P-ISSN 0000-0000, E-ISSN 0000-0000

Jurnal ABDIMAS Vol.1,No.1,Agustus 2019, Hal (118-126)

@Prodi Manajemen Fakultas Ekonomi Universitas Pamulang

Email: abdimasjurnal.unpam@gmail.com Telp: (021) 741-2566 meningkatkan kemampuan resiliensi individu, tidak terkecuali remaja yang tinggal di panti asuhan. Panti Asuhan Al Mubarokah merupakan salah satu panti asuhan yang mempunyai latar belakang keagamaan, sehingga setiap anak yang tinggal di panti diberikan bekal agama setiap harinya. Hal ini diupayakan untuk memperluas pengetahuan agama dan mempertinggi tingkat religiusitas anak. Namun, tidak semua remaja yang tinggal di panti mempunyai religiusitas yang baik.

Sebagian remaja panti melakukan aktivitas keberagamaan karena remaja panti tidak memiliki pilihan lain, sehingga harus menjalankannya. Remaja panti harus melakukan berbagai macam kegiatan yang berhubungan dengan keagamaan dan kegiatan lainnya dari pagi sampai malam karena hal tersebut merupakan suatu kewajiban yang mau tidak mau harus dipatuhi dan dilaksanakan.

$\begin{array}{rrrr}\text { Menurut } & \text { Wagnid dan } & \text { Young } \\ \text { (dalam Reich, dkk, 2010) } & \text { dalam }\end{array}$ mengembangkanMenurut Wagnid dan Young (dalam Reich, dkk, 2010) dalam mengembangkan resiliensi, peran religiusitas cukup penting, karena salah satu faktor internal yang mempengaruhi resiliensi adalah religiusitas. Menurut Hardjana (dalam Ghufron \& Risnawita, 2010), religiusitas adalah perasaan dan kesadaran akan hubungan dan ikatan kembali dengan Allah. Religiusitas menunjuk pada ketertarikan Individu terhadap agamanya dengan menghayati dan menginternalisasikan ajaran agamanya sehingga berpengaruh dalam segala tindakan dan pandangan hidupnya.
Jika religiusitas yang dimiliki remaja tinggi maka akan berpengaruh pula pada kemampuan resiliensinya sehingga akan terbentuk sikap- sikap positif, begitu juga sebaliknya religiusitas yang rendah akan mempengaruhi kemampuan resiliensi individu sehingga sikap-sikap yang terbentuk pada diri individu cenderung negatif.

\section{Perumusan Masalah}

Berdasarkan latar belakang
permasalahan di atas, mempertimbangkan latar belakang yang telah diutarakan diatas kami berinisiatif untuk membentuk kegiatan pengabdian masyarakat bagi anak anak panti usia dini adalah: apakah ada hubungan antara religiusitas dengan resiliensi pada remaja di Panti Asuhan Keluarga Yatim Almubarokah Tujuan ProgramTujuan dalam pengabdian masyarakat ini adalah untuk mengetahui :

1. Hubungan antara religiusitas dengan resiliensi pada remaja di Panti Asuhan Keluarga Yatim Almubarokah di Desa Cipayung Ciputat

2. Tingkat religiusitas pada remaja di Panti Asuhan Keluarga Yatim Almubarokah di Desa Cipayung Ciputat

3. Tingkat resiliensi pada remaja di Panti Asuhan Keluarga Yatim Almubarokah di Desa Cipayung Ciputat

4. Sumbangan efektif (SE) religiusitas terhadap resiliensi pada Almubarokah di Desa Cipayung Ciputat. 


\section{JURNAL ABDIMAS

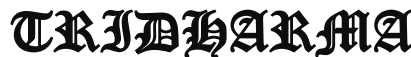

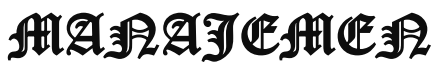

P-ISSN 0000-0000, E-ISSN 0000-0000

Jurnal ABDIMAS Vol.1,No.1,Agustus 2019, Hal (118-126)

@Prodi Manajemen Fakultas Ekonomi Universitas Pamulang

Email: abdimasjurnal.unpam@ gmail.com Telp: (021) 741-2566

\section{Tinjauan Pustaka}

\section{Pengertian Manajemen}

Pengertian manajemen secara umum merupakan kegiatan untuk mengatur, memimpin, mengelola, mengembangkan dan mengendalikan. Ilmu manajemen merupakan sebuah kajian ilmu dan seni perencanaan, pengarahan, pengorganisasian dan pengawasan terhadap usaha yang dilakukan oleh anggota organisasi serta pemanfaatan sumber daya yang tersedia untuk mencapai tujuan organisasi yang telah dimanfaatkan sebelumnya.

Manajemen juga dapat didefinisikan sebagai sebuah seni. didefinisikan sebagai sebuah seni karena manajemen seni dalam menyelesaikan pekerjaan melalui hubungan kerja sama antara satu dengan yang lainnya. Seni manajemen terdiri atas kemampuan melihat totalitas pada bagian yang terpisah dari bagian kesatuan gambaran tentang visi tertentu. Seni dalam hal ini mencakup kemampuan komunikasi sebuah visi meliputi aspek komunikasi, perencanaan kepemimpinan dan pengambilan satu keputusan. Pada intinya manajemen merupakan seni untuk mengelola dan mengatur.

Berdasarkan sumber nya pengertian manajemen pada umumnya banyak dikemukakan oleh para ahli diantara lain misalnya pengertian manajemen menurut Paul Hersey dan Kenneth, manajemen adalah usaha yang dilakukan dengan dan bersama individu atau kelompok. Elemen dasar manajemen meliputi elemen sifat, fungsi, sasaran, dan tujuan. Di sisi lain pengertian manajemen dapat didedfinisikan oleh Menurut Harold Koontz dan Cyril O'Donnell dalam bukunya The Principles of Managementmengatakan bahwa manajemen adalah cara untuk mencapai tujuan tertentu melalui kegiatan orang lain.

\section{FungsiManajemen}

Perencanaan adalah suatu uproses untuk menentukan rencana, sehingga rencana merupakan produk dari perencanaan. Dalam suatu rencana harus ditetapkan tujuan yang ingin dicapai dan pedomanpedoman untuk mencapai tujuan itu. Jadi, setiap rencana harus mengandung dua unsur yaitu tujuan dan pedoman.

\section{A. Perencanaan (Planning)}

Planning rerupakan
suatu aktivitas menyusun, tujuan
perusahaan lalu dilanjutkan
dengan menyusun berbagai
rencana-rencana guna mencapai
tujuan perusahaan yang sudah
ditentukan.
dilaksanakan dalam penentuan
tujuan organisasi scara
keseluruhan dan merupakan
langkah yang terbaik untuk
mencapai tujuannya itu. pihak
manajer mengevaluasi berbagaii
rencana alternatif sebelum
pengambilan tindakan kemudian
menelaah rencana yang terpilih
apakah sesuai dan bisa
dipergunakan untuk mencapai
tujuan.

Perencanaan adalah proses awal yang paling penting dari seluruh fungsi manajemen, karena fungsi yang lain tak akan bisa bejalan tanpa planning.

\section{B. Pengorganisasian (Organizing)}




\section{JURNAL ABDIMAS

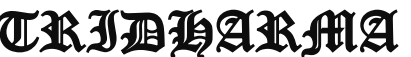

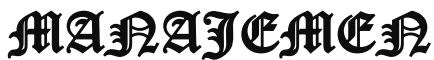

P-ISSN 0000-0000, E-ISSN 0000-0000

Jurnal ABDIMAS Vol.1,No.1,Agustus 2019, Hal (118-126)

@Prodi Manajemen Fakultas Ekonomi Universitas Pamulang

Email: abdimasjurnal.unpam@ gmail.com Telp: (021) 741-2566
Pengorganisasian

menurut Drs. H. Malayu S.P. Hasibuan dalam buku Manajemen Dasar, Pengertian dan Masalah, adalah "Suatu proses penentuan, pengelompokan, dan pengaturan bermacam-macam aktivitas yang diperlukan untuk mencapai tujuan, menempatkan orang-orang pada setiap aktivitas ini, menyediakan alat-alat yang diperlukan, menetapkan wewenang yang secara relatif didelegasikan kepada setiap individu yang akan melakukan aktivitas-aktivitas tersebut".

Organisasi atau pengorganisasian dapat pula dirumuskan sebagai keseluruhan aktivitas manajemen dalam mengelompokkan orang-orang serta penetapan tugas, fungsi, wewenang serta tanggung jawab masing-masing dengan tujuan tercapainya aktivitasaktivitas yang berdaya guna dan berhasil guna dalam mencapai tujuan yang telah ditetapkan terlebih dahulu.

\section{Pengarahan (Actuating)}

Menurut G.R Terry dalam buku Manajemen Dasar, Pengertian, dan Masalah edisi revisi, cetakan 1, Penerbit Bumi Aksara tahun 2001, Jakarta, halaman 137 yang ditulis olehDrs. $\quad H . \quad$ Malayu S.P. Hasibuan,"Pengarahan adalah membuat semua anggota kelompok agar mau bekerja sama dan bekerja secara ikhlas serta bergairah untuk mencapai tujuan sesuai dengan perencanaan dan usaha-usaha pengorganisasian".

\section{Pengawasan/Pengendalian (Controlling)}

Pengawasan/pengendalian menurut Earl P. Strongdalam buku Manajemen Dasar, Pengertian, dan Masalah, edisi revisi, cetakan 1, Penerbit Bumi Aksara tahun 2001, Jakarta, halaman 241 adalah proses pengaturan berbagai faktor dalam suatu perusahaan, agar pelaksanaan sesuai dengan ketepatan-ketepatan dalam rencana.

Menurut $M$. Manullang dalam buku Dasar-Dasar Manajemen, controlling atau pengawasan dan sering juga disebut pengendalian adalah "salah satu fungsi manajemen yang berupa mengadakan penilaian, bila perlu mengadakan koreksi sehingga apa yang dilakukan bawahan dapat diarahkan ke jalan yang benar dengan maksud tercapai tujuan yang sudah digariskan semula". Dalam melaksanakan kegiatan controlling, atasan mengadakan pemeriksaan, mencocokkan, serta mengusahakan agar kegiatan-kegiatan yang dilaksanakan sesuai dengan rencana yang telah ditetapkan serta tujuan yang ingin dicapai.

\section{Pengawasan/pengendalian}

menurut G.R. Terry dalam buku Manajemen Dasar, pengertian, dan Masalah, edisi revisi, cetakan 1, Penerbit Bumi Aksara tahun 2001, Jakarta, halaman 242 adalah sebagai proses penentuan, apa yang harus dicapai yaitu standar, apa yang sedang dilakukan yaitu pelaksanaan, menilai pelaksanaan sesuai dengan rencana yaitu selaras dengan standar. 


\section{JURNAL ABDIMAS

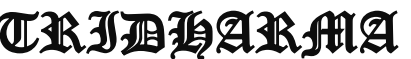

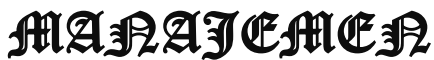

P-ISSN 0000-0000, E-ISSN 0000-0000

Jurnal ABDIMAS Vol.1,No.1,Agustus 2019, Hal (118-126)

@Prodi Manajemen Fakultas Ekonomi Universitas Pamulang

Email: abdimasjurnal.unpam@ gmail.com Telp: (021) 741-2566
Pengawasan/pengendalian teknis (technical control)menurut Drs. H. Malayu S.P Hasibuan dalam buku Manajemen Dasar, Pengertian, dan Masalah, edisi revisi, cetakan 1, Penerbit Bumi Aksara tahun 2001, Jakarta, halaman 244 adalah pengendalian yang ditujukan kepada hal-hal yang bersifat fisik, yang berhubungan dengan tindakan dan teknis pelaksanaan.

\section{Pengertian Manajemen Sumber Daya Manusia}

Manajemen adalah ilmu dan seni yang megatur proses pemanfaatan sumber daya manusia dan sumbersumber daya lainya secara efektif dan efesien untuk mencapai suatu tujuan tertentu.

Manajemen sumber daya manusia merupakan bagian dari ilmu manajemen yang memfokuskan perhatianya pada pengaturan peranan sumber daya manusia dalam kegiatan organisasi. Hal ini dikarnakan dalam mencapai tujuanya, organisasi memerlukan sumber daya manusia sebagai pengeelola sistemnya, dan agar sistem ini berjalan, dalam pengelolaanya diperlukan beberapa aspek penting, seprti pelatihan, pengembangan, motivasi dan aspek-aspek lainya. Hal ini yang menjadikan manajeman sumber daya manusia sebagai salah satu indikator penting pencapaian tujuan organisasi secara efektif dan efisien.( mila badriah, S.E.,M.M, 15: 2015).
Manusia selalu berperan aktif dan dominan dalam kegiatan organisasi karena manusia menjadi perencana, pelaku, dan penentu terwujudanya tujuan organisasi. Tujuan tidak mungkin terwujud tanpa peran aktif tanpa peran karyawan meskipun alatalat yang dimiliki oleh perusahaan begitu canggih. Alat-alat canggih perusahaan tidak ada manfaatnya bagi perusahaan, jika peran aktif karyawan tidak di ikut sertakan. Mengatur karyawan merupakan hal yang sulit dan kompleks karena mereka mempunyai pikiran, perasaan, status, keinginan, dan latar belakang yang heterogen yang dibawa kedalam suatu organisasi. Karyawan tidak dapat di atur dan dikuasai sepenuhnya seperti mengatur mesin, moda, dan gedung.

Manajemen sumber daya manusia merupakan bagian dari manajemen. Oleh karna itu, teori-teori manajemen umum manjadi dasar pembahasaannya mengenai pengaturan peranaan manusia dalam menentukan tujuan yang optimal.

Pengaturan itu meliputi masalah perencanaan (human resources planning),

pengorganisasian,pengarahaan,kompen asasi,pengintregrasian,pemeliharaan,ke disiplinan dan pemberhentian tenaga kerja untuk membantu terwujudnya tujuan perusahaan, karyawan, dan masyarakat.

Pengertian manajeman sumber daya manusia menurut malyu S.P. hasibuan ( 2005: 10 ) yang menyatakan bahwa : 


\section{JURNAL ABDIMAS

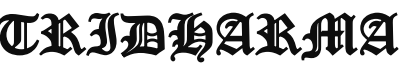

"manajeman sumber daya manusia adalah ilmu dan seni yang mengatur hubungan dan peranan tenaga kerja yang efektif dan efisien membantu terwujudnya tujuan perusahaan, karyawan, dan masyarakat.

3. Pengertian Aqidah

Akidah merupakan dasar bangunan syariah. Sejauh mana kita mengenal, mengerti, dan menghayati dasar-dasar akidah akan menentukan kualitas keberagamaan dan kehidupan kita.

Ditopang kedalaman ilmu dan kelugasan seorang dai-cendekiawan, Profesor Muhammad menyajikan pokok-pokok akidah Islam yang bersumber dari Al-Quran dan Sunnah.

\section{METODOLOGI}

PELAKSANAAN

\section{PROGRAM}

Metodepelaksanaan pengabdian ini dilakukan dalam beberapa kegiatan yaitu tahap survei yaitu sosialisasi dilakukan dengan menyusun berbagai hal yang akan disampaikan pada saat kegiatan pengabdian yang akan dilakukan yang meliputi: penyusunan materi yang akan diberikan, penyusunan jadwal pemberian materi, pembagian tugas tim pengabdian dan survei ke lokasi pengabdian.

Tahap sosialisasi yaitu sebelum kegiatan pengabdian dilaksanakan terlebih dahulu dilakukan tahap sosialisasi yaitu melakukan silaturahmi dengan ketua yayasan, menyampaikan maksud dan tujuan pengabdian ini. Pada tahap ini juga dilakukan jalinan kerjasama dan menentukan jadwal kegiatan pengabdian.

Tim pelaksana kegiatan pengabdian pada masyarakat adalah dosen Fakultas Ekonomi jurusan manajemen sebanyak 11 orang. Tim pengabdian memberikan materi tentang pembinaan aqidah pada anak - anak usia dini dan akan memberikan pelatihan disana oleh dosen UNPAM dan bekerja sama dengan Yayasan Panti Asuhan Yatim Piatu Al Mubarakah.

\section{HASIL DAN PEMBAHASAN}

Pengabdian Masyarakat (LPPM) Universitas Pamulang yang dilakukan oleh dosen-dosen program studi Manajemen telah berjalan dengan lancar dan mendapat sambutan hangat dari tempat pelaksanaan kegiatan ini yaitu di Yayasan Panti Asuhan Yatim Piatu Al MubarakahCipayung

Harapan kami dengan pengabdian ini dapat memotivasi anak -anak usia dini untuk meningkatkan reguilitas atau keagamaan (keimanan dan ketaqwaan terhadap Allah Subhananu Wata A'la) serta dapat beperilaku baik ,mempunyai adab dan sopan santun kepada sesama manusia.

\section{KESIMPULAN DAN SARAN}

Kesimpulan 

JURNAL ABDIMAS
P-ISSN 0000-0000, E-ISSN 0000-0000

Peserta kurang mengerti bagaimana cara meningkatkan nilai keagamaan yang hakiki serta menjadi manusia yang bermanfaat untuk sesama umat manusia, dan arti penting dari pembinaan aqidah pada anak -anak usia dini disarankan kepada orang tua untuk memberikan bimbingan serta memotivasi anak -anak untuk beriman dan bertaqwa kepada Allah Subhananhu Wata A'la ,berperilaku baik dan beradab.

\section{Saran}

Setelah pengabdian ini diharapkan peserta dapat memiliki hidup yang lebih sehat secara rohani serta dapat bertambahnya keimanan dan ketaqwaan terhadap Allah Subhanahu Wata'Ala ,berperilaku baik, bermoral dan mempunyai nilai keagamaan yang tinggi. Serta dapat menghimbau teman - teman yang lainnya guna memberikan motivasi dalam rangka meningkatkan aqidah dan akhlak sesama umat muslim

\section{DAFTAR PUSTAKA}

Chirzin, Muhammad .Mag Prof. Dr .Buku Saku Konsep dan Hikmah Akidah Islam .2015.Jakarta.

. H. Malayu S.P. Hasibuan dalam buku Manajemen Dasar, Pengertian dan Masalah, edisi revisi, cetakan 1, Penerbit Bumi Aksara tahun 2001, Jakarta, halaman 93,

Pasaribu, V. L. D., Susanti, F., \& Hartuti, E. T. K. (2019). MEMOTIVASI SISWA DAN SISWI SMK LETRIS INDONESIA DI DALAM MENENTUKAN PILIHAN UNTUK MELANJUTKAN PENDIDIKAN ATAU BEKERJA SETELAH LULUS
SEKOLAH. Jurnal Pengabdian Dharma Laksana, 1(2), 161-172.

Siswanto, Dr. H.B.M.Si .2011.Pengantar Manajemen. Jakarta. Bumi Aksara

G.R. Terry dalam buku Manajemen Dasar, Pengertian dan Masalah, edisi revisi, cetakan 1, Penerbit Bumi Aksara tahun 2001, Jakarta, halaman 85, 